\title{
Corporate Governance, Cash holdings and Value of a Firm: Evidence from Australian Firms
}

\author{
Subba Reddy Yarram \\ UNE Business School, University of New England, Armidale NSW, Australia \\ syarram@une.edu.au
}

\begin{abstract}
The present study analyses influence of board structure and cash holdings on the value of Australian firms for the period 2004 to 2010. Australian Stock Exchange (ASX) adopted the Principles of Good Corporate Governance Guidelines in 2003 and Australian firms have started adopting these principles starting 2004. Similarly the reporting framework of Australian firms is harmonized with the rest of the world with adoption of Australian International Financial Reporting Standards (AIFRS) starting in 2004. Corporate cash holdings despite their significance have not been considered extensively in prior literature outside the US. Cash holdings may have significant influence on the value of the firm as too much excess cash may lead to misuse of these funds by entrenched managers. Corporate governance has a role to play in maintaining appropriate cash holdings and their use. The present has two objectives: it considers the influence of corporate cash holdings on the value of Australian firms; and it examines the role of board structure on the relationship between cash holdings and value of the firm. The present study considers all non-financial firms that are part of the All Ordinaries Index (AOI). The present study constructs Fama French 25 portfolio and estimate the excess return as the difference between actual return and the average return of the relevant FF portfolio. OLS analyses show that board independence has no significant impact on the value of the firm though cash holdings have significant influence. Analysing using panel data methods however unearth the significant influence of board independence on the value of Australian firms.
\end{abstract}

Keywords: Corporate governance, Cash holdings; Panel data analysis

\section{Introduction}

Cash holdings are an important consideration for corporate firms given the many purposes that cash and its equivalents provide. Cash holdings help firms meet not only day to day transactions but help firms meet contingencies that may arise from unanticipated events and also help them take on opportunities that may arise. Cash holdings or broadly liquidity helps firms to undertake investment opportunities without having to incur significant transaction costs though either debt or equity issues (Faulkender \& Wang, 2006). However, cash holdings may also present opportunities for managers to invest in suboptimal projects and empire building (Jensen \& Meckling, 1976). Similarly corporations pay a higher tax on interested earned on their cash holdings compared to investors and this may mean a dollar in cash may add less than a dollar of value. Savings on transaction costs and the benefits of precautionary holdings may mean a dollar of cash adds more than a dollar of value to firms. The present study extends the empirical literature on corporate cash holdings in several ways. First, it considers a market characterized by tax imputation system that avoids double taxation. Second, the present study considers board characteristics and their influence on cash holdings and value of firm as governance is likely to influence the use or misuse of cash balances. Third, the present study controls for endogeneity and unobserved heterogeneity. The present has two objectives: it considers the influence of corporate cash holdings on the value of Australian firms; and it examines the role of board structure on the relationship between cash holdings and value of the firm.

\section{Literature Review}

Corporate firms hold cash balances mainly for transaction, precautionary and speculative purposes. Cash balances help firms perform day to day activities or meet the transactional needs. Apart from this firms may also hold cash for meeting unanticipated expenses as well as for speculative purposes. Growing firms are likely to hold higher balances of cash with a view to reduce the cost of external financing. Kim, Mauer, and Sherman (1998)propose a trade-off model of liquidity that positively relates liquidity with cost of external funds, riskiness of expected cash flows and expected return on investments and that negatively relates liquidity with return on present investments. Firms hold optimal liquidity where the 
benefits of holding liquid investments are just equal to marginal cost of holding such investments. Opler, Pinkowitz, Stulz, and Williamson (1999)also find that for a sample of US firms for the period 1971 to 1994 high cash balances are positively associated with growth opportunities, riskiness of cash flows and firm profitability. Firms with better access to capital markets and higher credit ratings on the other hand hold lower cash balances. They find no evidence of firms with excess cash resorting to higher capital expenditure or acquisitions and paying out higher dividends. Operating losses have a significant impact on the changes in excess cash. Ozkan and Ozkan (2004)analyse the determinants of corporate cash holdings of a sample of UK firms for the period 1984 to 1999. They find evidence of non-linear relationship between cash holdings and managerial ownership. At low levels of managerial ownership, companies hold lower cash balances as the ownership rises but after a threshold level of ownership, the cash balances rise with ownership and finally at very high levels of managerial ownership cash balances again fall with the rise in ownership. They find that the effect of managerial ownership persists and is unaffected by variations in board composition as well as when controlled for other effects. In the absence of agency costs, one dollar of cash holdings should be equal to one dollar of value for the firm. On the other hand in the presence of agency costs, one dollar of cash holdings will have a lower value for the firm and the value of cash holdings is dependent on investor protection and governance mechanisms. Firms in countries characterized by low investor protection have lower value of cash holdings compared to countries where investor protection is stronger (Pinkowitz, Stulz, \& Williamson, 2006).

Marginal benefits and costs of cash holdings may ultimately determine the impact that cash holdings have on the value of a firm. Faulkender and Wang (2006)find that value of cash balances declines with larger cash holdings, higher leverage, greater access to financial markets and their choice of dividends over repurchases when distributing cash to shareholders. Size of a firm is likely to influence cash holdings of firms. Smaller firms are likely to hold larger cash balances compared to larger firms (Chang \&Noorbakhsh, 2006). For a sample of 22,000 firms from 48 countries, Chang and Noorbakhsh (2006) find that firms in countries with greater investor protection hold lower cash ratios. Dittmar and MahrtSmith (2007) identify three reasons why cash is important for the value of a firm: ease of access managers have flexibility in terms of using cash for discretionary purposes; increased trend in holding cash balances - cash holdings constitute a significant proportion of value held by companies; and volatility in cash holdings - firm level cash holdings have fluctuated widely. They find that corporate governance has a significant impact on the value of cash holdings. A $\$ 1$ of cash has only a value of $\$ 0.42$ to $\$ 0.88$ in firms that are poorly governed and that this value doubles when firms are well governed. Similarly they find that poor governance leads to inefficient use of cash leading to poor operating performance. Drobetz and Grüninger (2007) analyse the cash holdings of a firms of Switzerland for the period 1995 and 2004 and find that Swiss firms hold on average twice as much cash as that of the US and UK firms. They also find evidence of non-linear relationship between managerial ownership and cash holdings of Swiss firms and that firms that have CEO-Chairman duality have on average more cash holdings. Harford, Mansi, and Maxwell (2008) analyse the influence of corporate governance on the cash holdings of firms in the US for the period 1993 to 2004. In weakly governed firms corporate cash holdings are smaller and that these firms quickly use up cash in acquiring firms and other capital expenditure. Similarly poorly governed firms payout cash in the form of share repurchases rather than paying dividends with a view to avoid future commitments associated with dividend payments. They also find that firms with weaker governance structures and excess cash holdings to be less profitable and often have poor valuations.

Chen and Chuang (2009) underline the importance of investment or growth opportunities in determining the influence of corporate governance on cash holdings of firms. Corporate governance ensure that investors interests are protected when firms hold large cash holdings and that firms will invest these cash balances in positive value adding projects. They find that ownership held by CEO, presence of venture capitalists on the board and board independence play a significant role in determining the cash holdings of firms. They also find that corporate governance is particularly significant in the case of younger firms. Lee and Lee (2009) analyse the influence of board structure and managerial ownership on the value of corporate cash holdings. They find that firms with smaller boards, highly independent boards and lower managerial shareholding have lower cash holdings. They also find negative association between cash holdings and firm value is highly significant in the case of firms less outside directors, larger boards and higher managerial ownership. They conclude that firms with large cash holdings and higher managerial ownership face significant valuation discount as investors are concerned about the opportunities for managers to invest in sub-optimal projects. A few earlier studies have conducted surveys to elicit the views of managers with regard to corporate cash and liquidity policies. Lins, Servaes, and Tufano (2010) 
survey financial officers from 29 countries with regard to their use of lines of credit versus nonoperational cash. They find that firms use lines of credit when credit markets are not well developed and that majority of use lines of credit as a dominant source of liquidity. They conclude that firms employ non-operational cash holdings as a cushion against future cash flow shocks while credit lines provide them options to pursue investment opportunities that may arise in future. Powell and Baker (2010) on the other hand find that managers believe that governance mechanisms influence the cash holdings and how the cash is spent but managers do not believe that governance impacts the value of cash holdings.

Frésard and Salva (2010) find the positive effects of cross listings of firms. They find that firms that have cross listing on the US exchanges and the over-the-counter markets have better valuations than their domestic peers. Cross listing helps firm derive higher valuations from excess cash holdings compared to firms that do not cross list. They conclude that US cross listing helps rein insider misuse of funds. Kuan, $\mathrm{Li}$, and Chu (2011) examine the role corporate governance plays in the corporate cash holding policy of Taiwanese family owned firms. They find that the influence of managerial ownership and board independence have different impacts on family firms compared to their impact on non-family firms. Kuan, Li, and Liu (2012) confirm these results with regression approach. Kusnadi (2011) analyse the influence of corporate governance structure on the corporate cash holdings and valuation of Malaysian and Singaporean firms. They find evidence of weak governance and higher levels of cash holdings for firms in both countries. They also find that investors discount the value of firms with higher cash holdings in the presence of poor governance mechanisms. They also show that duality, pyramidal ownership structure and family control of firms have significant negative impact on the value of firms. They conclude that the discounted valuation is the result of investors' concern relating to entrenchment of managers. Liu and Mauer (2011) analyse the relationship between CEO compensation, corporate cash holdings and the value of corporate firms. They find a positive relationship between risk-taking incentives of CEOs and corporate cash holdings and a negative relationship between risk-taking incentives of CEOs and value of cash to shareholders. They find that the negative effect of risk-taking incentives does not exist in the case of financially constrained firms and is present in the case of levered firms. Most of the prior literature focused on the US and UK context. Therefore the present study examines the trends in cash holdings in Australia and examines the association between corporate governance, cash holdings and the value of firms.

\section{Methodology}

The initial sample for this study consists of all non-financial firms listed on the Australian Stock Exchange (ASX). Financial firms are excluded given the nature of their business activity and the amount of regulation that they are subject to. Similarly firms from real estate sector are excluded given their similarity to financial services. The final sample consists of 4631 firm years for 662 firms (Table 01). Sample firms are distributed across a wide range of sectors with basic material, energy, consumer cyclicals, industrials and healthcare sectors accounting for a major proportion. The study period of 2004 to 2010 is considered as the ASX has adopted the 'Principles of Good Corporate Governance and Best Practice Recommendations' in March 2003. Similarly Australia has adopted the Australian International Financial Reporting Standards (AIFRS) starting in 2004 and the study period represents a new reporting framework. In terms of macroeconomic conditions, despite the recent global financial crisis (GFC), Australia continued to have significant core strength with inflation and unemployment under control.

\begin{tabular}{|l|r|r|r|r|r|r|r|r|}
\hline Table 01: Distribution of sample firms across sectors & & & \\
\hline Sector & 2004 & 2005 & 2006 & 2007 & 2008 & 2009 & 2010 & Total \\
\hline & & & & & & & & \\
\hline Basic Materials & 220 & 223 & 223 & 223 & 223 & 223 & 223 & 1558 \\
\hline Consumer Cyclicals & 93 & 93 & 93 & 93 & 93 & 93 & 93 & 651 \\
\hline Consumer Non-Cyclicals & 26 & 26 & 26 & 26 & 26 & 26 & 26 & 182 \\
\hline Energy & 104 & 104 & 104 & 104 & 104 & 104 & 104 & 728 \\
\hline Healthcare & 61 & 61 & 61 & 61 & 61 & 61 & 61 & 427 \\
\hline Industrials & 86 & 86 & 86 & 86 & 86 & 86 & 86 & 602 \\
\hline Technology & 46 & 46 & 46 & 46 & 46 & 46 & 46 & 322 \\
\hline Telecommunications & 14 & 14 & 14 & 14 & 14 & 14 & 14 & 98 \\
\hline Utilities & 9 & 9 & 9 & 9 & 9 & 9 & 9 & 63 \\
\hline Total & 659 & 662 & 662 & 662 & 662 & 662 & 662 & 4631 \\
\hline
\end{tabular}


Financial information such as market capitalization, cash holdings, earnings, net assets, R\&D, inventory, dividend payout, long-term debt, net financing cash flows, free cash flow, net working capital and intangibles is sourced from DataStream. Independence, duality and board size measures are constructed based on the information sourced from SIRCA database. To examine the influence of cash holdings and corporate governance on the value of Australian firms, first Fama French (FF) 25 portfolios are constructed for all the firms for which total return data is available from DataStream for the period 2004 to 2010 (Fama \& French, 1993). Similar to Fama and French, quintiles of market capitalization and market to book value are formed first. Based on these quintiles, 25 portfolios are formulated that include firms with large size and high growth on one end of the spectrum and small size and low growth on the other extreme with intermediate portfolios representing combinations of size and growth. Two separate sets of 25 portfolios are formulated on market capitalization weighted and equal weighted bases. Excess return is calculated as the difference between observed total return and the relevant portfolio return. ERw and EReq measure the excess return based on market capitalization weighted portfolios and equally-weighted portfolios respectively (Table 02). Use of both measures of excess returns helps in establishing the validity of the results.

\begin{tabular}{|c|c|}
\hline Variable & Definition or explanation \\
\hline ChtCash & Change in cash holdings \\
\hline Cht2Cash & Change in cash holdings over the last two years \\
\hline ChtEarn & Change in earnings \\
\hline ChtNA & Change in net assets (excluding cash holdings) \\
\hline ChtRD & Change in R\&D \\
\hline ChtInv & Change in inventory \\
\hline ChtDiv & Change in dividend payout \\
\hline Lit & Long-term debt \\
\hline NFit & Net financing cash flows \\
\hline FCFMV & Free cash flow \\
\hline NWCMV & Net working capital (excluding cash holdings) \\
\hline IntngMV & Intangibles \\
\hline ERw & Excess return based on weighted average FF portfolio \\
\hline EReq & Excess return based on equal weighted average FF portfolio \\
\hline CashMv & Cash holdings \\
\hline LnMV & Natural logarithm of market capitalization \\
\hline Independence & Proportion of independent directors on a board \\
\hline Duality & CEO-Chairman duality. 1 indicates duality 0 indicates separation \\
\hline BoardSize & Number of board of directors on a board \\
\hline
\end{tabular}

\section{Results}

Cash holdings of Australian firms are an average 32.2 per cent of market value (Table 03). This is comparable to firms in the US and UK. Cash holdings declined from 37.8 per cent of market value in 2004 to 25.2 per cent in 2005 before gradually increasing to 42.1 per cent in 2007 . They dropped from this peak to 16.9 per cent in 2009 before recovering to the highest level of 48.5 per cent in 2010 . On the whole cash holdings as a per cent of market value have fluctuated widely during the study period (Table 04). Average excess returns on average for the sample firms over the period 2004 to 2010 is 1 per cent on an weighted average basis and is a negative 3.3 per cent on the equal weighted basis. Excess returns on the whole fluctuated widely during the study period with a high of 6.6 per cent in 2007 and a low of a negative 8.1 per cent in 2010 on market value weighted basis. On equal weighted basis, the fluctuations are even higher with a high of 1.5 per cent in 2008 and a low of a negative 22.2 per cent in 2010. Board characteristics have also undergone gradual change over the study period particularly in terms of board independence and CEO-Chairman duality. Median board independence at 75 per cent for the sample period compares well with many OECD countries. Board independence increased steadily from 67.5 per cent in 2004 to 73.6 per cent in 2010. CEO-Chairman duality on the other hand had gradually declined 
from an already low level of around 8 per cent to 4.7 per cent in 2010. Board size has shown steady levels during the entire sample period and the average board size of Australian firms stood at around 6 . Changes in board composition better reflect the recent thrust on good governance. Average Australian board size is neither too small nor too large at an average board size of 6 members. Majority of these board members are now overwhelmingly non-executive or independent directors. Similarly the numbers of boards which have the same person performing the Chairperson and the CEO rule have fallen further and stand at 4.7 per cent in 2010.

\begin{tabular}{|c|c|c|c|c|c|c|c|c|c|}
\hline \multicolumn{6}{|c|}{ Table 03: Descriptive statistics for variables employed } & \multirow[b]{2}{*}{ p75 } & \multirow[b]{2}{*}{$\max$} & \multirow[b]{2}{*}{ skewness } & \multirow[b]{2}{*}{ kurtosis } \\
\hline variable & ean & sd & $\min$ & $\mathrm{p} 25$ & p50 & & & & \\
\hline ChtCash & 0.090 & 0.782 & -28.975 & -0.042 & 0.004 & 0.092 & 20.782 & -2.858 & 590.370 \\
\hline Cht2Cash & 0.116 & 0.791 & -6.768 & -0.039 & 0.014 & 0.129 & 29.026 & 17.711 & 557.054 \\
\hline ChtEarn & -0.002 & 2.262 & -139.350 & -0.067 & 0.008 & 0.085 & 16.800 & -52.469 & 3239.683 \\
\hline ChtNA & 0.184 & 1.326 & -11.715 & -0.062 & 0.025 & 0.179 & 28.278 & 8.904 & 150.276 \\
\hline ChtRD & 0.004 & 0.082 & -0.005 & 0.000 & 0.000 & 0.000 & 4.272 & 42.036 & 1992.997 \\
\hline ChtInv & 0.047 & 0.496 & -5.508 & -0.011 & 0.001 & 0.026 & 17.850 & 20.496 & 671.230 \\
\hline ChtDiv & 0.002 & 0.046 & -1.130 & 0.000 & .000 & 0.000 & 1.046 & 1.800 & 263.665 \\
\hline Lit & 0.287 & 0.862 & 0.000 & 0.000 & .029 & 0.265 & 18.933 & 9.896 & 145.956 \\
\hline NFit & 0.298 & 1.686 & -4.117 & -0.020 & 0.047 & 0.267 & 81.225 & 30.352 & 1287.319 \\
\hline FCFMV & -0.164 & 2.346 & -144.250 & -0.187 & -0.033 & 0.076 & 15.754 & -51.659 & 3101.513 \\
\hline NWCMV & -0.047 & 0.579 & -10.663 & -0.081 & -0.011 & 0.052 & 6.647 & -3.947 & 73.347 \\
\hline IntngMV & 4 & 0 & 0 & 0 & 002 & 0.198 & 24.957 & 17 & 9.524 \\
\hline ERw & 0.010 & 0.851 & -3.436 & -0.404 & -0.107 & 0.224 & 6.946 & 2.211 & 13.406 \\
\hline EReq & -0.033 & 0.840 & -3.532 & -0.449 & -0.132 & 0.191 & 6.263 & 2.123 & 12.834 \\
\hline Casl & 322 & 0.808 & 000 & .041 & 0.123 & 0.333 & 0.890 & 16.767 & 475.126 \\
\hline LnMV & 3.830 & 2.164 & 3.507 & 2.257 & 3.400 & 5.105 & 11.883 & 0.714 & 3.231 \\
\hline Independence & 0.700 & 0.171 & 0.000 & 0.600 & 0.750 & 0.833 & 0.938 & -0.919 & 3.870 \\
\hline Duality & 0.068 & 0.252 & 0.000 & 0.000 & 0.000 & 0.000 & 1.000 & 3.423 & 12.714 \\
\hline BoardSize & 5.950 & 2.338 & 3.000 & 4.000 & 5.000 & 7.000 & 17.000 & 1.202 & 4.931 \\
\hline
\end{tabular}

An examination of correlations is undertaken to rule out the possibility of multicollinearity in the variables employed (Table 5). The two excess returns measured are highly significantly positively related. Given that only one variable will be employed at any one point in time, these high correlations do not pose any problems for further analysis. Correlations relating to board characteristics with other variables are low indicating their appropriateness in the analysis. Net financing cash flows and free cash flow are positively significant with high correlation values. Free cash flows are only employed when estimating the expected level of cash flows for the firms and net financing cash flows are not part of this analysis. Net financing cash flows are only employed when estimating the impact of cash holdings and board characteristics on the value of firms. The empirical analysis of influence of cash holdings and corporate governance on the value of firms is undertaken in three stages. In the first stage, excess returns are regressed on level of cash holdings as well as changes in cash holdings, governance and a set of other control variables using OLS analyses. In the second stage, expected cash holdings are estimated based on market value, free cash flow, net working capital and intangibles using a panel analysis framework. All the variables employed are standardized by market value. Excess cash holdings are calculated by subtracting the expected cash flows from the actual cash flows. In the third stage, excess cash holdings are regressed on the independent variables employed in the first stage using fixed effects panel analysis.

In OLS analyses as well as fixed effects panel data analyses a total of 6 models are employed for excess returns calculated on market value weighted basis and equal weighted basis (Table 06). The first 3 models pertain to excess returns calculated on the basis of market value weighted basis and models 4 to 6 employ excess returns calculated on equal value basis. Models 1 and 4 capture the influence of level of cash holdings and changes in cash holdings, earnings, and net assets excluding cash holdings, research and development investments, inventory, dividends, as well as leverage and net financing cash flows on 
the excess returns. Models 2 and 5 incorporate interaction terms that capture level of cash holdings and change in cash holdings and leverage and level of cash holdings in addition to other financial variables included in Models 1 and 4. Models 3 and 6 include governance variables in addition to variables employed in Models 2 and 5. Models 1 and 4 show that level of cash holdings and changes in cash holdings have significant positive impact on the excess returns or the value of firms. Leverage on the other hand has significant negative influence on the value of firms. Models 2 and 5 show that the joint effect of leverage and level of cash holdings is negative on the value of firms, whereas Models 3 and 6 show that this joint effect does not persist when governance variables are included in the analysis. In the presence of governance variables, the joint effect of level of cash holdings and change in cash holdings is negative implying that at high levels of cash holdings, additional increases in cash holdings will have a negative influence on the value of the firms as investors are worried about the excess free cash flow available to managers. Board size has a significant negative impact on the value of firm, however this effect is not observed in the case of excess returns calculated on the basis of market value weighted portfolio.

\begin{tabular}{|c|c|c|c|c|c|c|c|c|}
\hline Year & 2004 & 2005 & 2006 & 2007 & 2008 & 2009 & 2010 & Total \\
\hline ChtCash & 0.078 & 0.059 & 0.115 & 0.203 & 0.066 & 0.006 & 0.104 & 0.090 \\
\hline Cht2Cash & & 0.102 & 0.135 & 0.269 & 0.120 & 0.018 & 0.053 & 0.116 \\
\hline ChtEarn & -0.118 & -0.003 & -0.040 & -0.007 & 0.002 & 0.006 & 0.147 & -0.002 \\
\hline ChtNA & 0.278 & -0.059 & 0.250 & 0.399 & 0.170 & -0.028 & 0.275 & 0.184 \\
\hline ChtRD & 0.003 & 0.003 & 0.003 & 0.009 & 0.004 & 0.001 & 0.008 & 0.004 \\
\hline ChtInv & 0.091 & 0.033 & 0.061 & 0.074 & 0.033 & 0.001 & 0.035 & 0.047 \\
\hline ChtDiv & 0.003 & 0.005 & 0.002 & 0.005 & 0.004 & 0.000 & -0.004 & 0.002 \\
\hline Lit & 0.285 & 0.253 & 0.269 & 0.248 & 0.201 & 0.468 & 0.285 & 0.287 \\
\hline NFit & 0.532 & 0.230 & 0.310 & 0.403 & 0.213 & 0.043 & 0.360 & 0.298 \\
\hline FCFMV & -0.384 & -0.100 & -0.171 & -0.138 & -0.083 & -0.077 & -0.196 & -0.164 \\
\hline NWCMV & -0.060 & -0.004 & -0.028 & -0.067 & -0.039 & -0.048 & -0.081 & -0.047 \\
\hline IntngMV & 0.301 & 0.248 & 0.220 & 0.216 & 0.215 & 0.150 & 0.430 & 0.254 \\
\hline ERw & 0.065 & 0.010 & 0.002 & 0.066 & 0.033 & -0.028 & -0.081 & 0.010 \\
\hline EReq & 0.004 & -0.011 & -0.006 & -0.022 & 0.015 & 0.012 & -0.222 & -0.033 \\
\hline CashMv & 0.378 & 0.252 & 0.298 & 0.421 & 0.249 & 0.169 & 0.485 & 0.322 \\
\hline LnMV & 3.398 & 3.616 & 3.761 & 4.145 & 4.376 & 3.454 & 4.057 & 3.830 \\
\hline Independence & 0.675 & 0.683 & 0.693 & 0.698 & 0.710 & 0.726 & 0.736 & 0.700 \\
\hline Duality & 0.079 & 0.085 & 0.074 & 0.058 & 0.059 & 0.065 & 0.047 & 0.068 \\
\hline BoardSize & 5.898 & 5.888 & 5.946 & 6.100 & 5.967 & 5.828 & 6.093 & 5.950 \\
\hline
\end{tabular}

Table 05: Correlations

ChtCash Cht2Cash ChtEarn ChtNA ChtRD ChtInv ChtDiv Lit NFit FCFMV NWCMV IntngMV ERw EReq CashMv LnMV

\begin{tabular}{|c|c|c|c|c|c|c|c|c|c|c|c|c|c|c|c|c|}
\hline Cht2Cash & 0.88 & & & & & & & & & & & & & & & \\
\hline ChtEarn & 0.56 & & & & & & & & & & & & & & & \\
\hline ChtNA & 0.17 & 0.20 & & & & & & & & & & & & & & \\
\hline ChtRD & 0.33 & 0.48 & & 0.06 & & & & & & & & & & & & \\
\hline ChtInv & & 0.42 & -0.61 & 0.28 & & & & & & & & & & & & \\
\hline ChtDiv & 0.06 & 0.13 & & 0.10 & & & & & & & & & & & & \\
\hline NFit & & 0.73 & -0.75 & 0.29 & 0.28 & 0.74 & & & & & & & & & & \\
\hline FCFMV & 0.45 & -0.12 & 0.94 & & -0.09 & -0.54 & & & -0.75 & & & & & & & \\
\hline NWCMV & & & 0.14 & -0.15 & 0.11 & -0.13 & & -0.21 & -0.17 & 0.19 & & & & & & \\
\hline IntngMV & & & & 0.44 & & & 0.09 & 0.18 & 0.09 & & -0.17 & & & & & \\
\hline ERw & 0.24 & 0.30 & & 0.20 & 0.13 & 0.17 & 0.07 & -0.06 & 0.20 & & & 0.08 & & & & \\
\hline EReq & 0.24 & 0.30 & & 0.20 & 0.13 & 0.17 & 0.06 & & 0.20 & & & 0.08 & 0.98 & & & \\
\hline CashMv & 0.72 & 0.89 & & 0.25 & 0.44 & 0.30 & 0.06 & & 0.51 & -0.08 & -0.08 & 0.08 & 0.36 & 0.36 & & \\
\hline LnMV & & & & & & & & & -0.08 & 0.08 & 0.06 & & 0.09 & & -0.11 & \\
\hline Independence & & & & & & & & & -0.07 & & & & & & & 0.23 \\
\hline \multicolumn{17}{|l|}{ Duality } \\
\hline BoardSize & & & & & & & & 0.07 & -0.08 & & & 0.10 & & -0.11 & -0.08 & 0.59 \\
\hline
\end{tabular}

Note: Only correlations significant at $1 \%$ are reported 
OLS analysis suffers from unobserved heterogeneity and hence the present study employs FE analyses to examine the level of expected cash flows and the influence of excess cash on the value of firms. Fixed effects panel data analysis shows that excess cash has a significant negative influence on the value of firms, whereas level of cash holdings has a significant positive influence (Table 07). Change in earnings, $R \& D$, dividends and net financing cash flows have positive influence on the value of firms where as leverage has a significant negative influence on the value of firms. Firms that have higher excess cash and independent boards add value to the firms and similarly larger boards add value to the firm when firms have excess cash holdings.

\begin{tabular}{|c|c|c|c|c|c|c|}
\hline \multicolumn{7}{|c|}{ Table 06: Influence of cash and governance on excess returns: OLS analyses } \\
\hline Model & (1) & (2) & (3) & (4) & (5) & (6) \\
\hline & ERw & ERw & ERw & EReq & EReq & EReq \\
\hline \multirow[t]{2}{*}{ ChtCash } & $0.3908^{* * *}$ & $0.4225^{* * *}$ & $0.4930^{* * *}$ & $0.3938^{* * *}$ & $0.4164^{* * *}$ & $0.4917^{* * *}$ \\
\hline & $(5.29)$ & $(5.59)$ & $(5.35)$ & $(5.17)$ & $(5.52)$ & $(5.40)$ \\
\hline \multirow[t]{2}{*}{ ChtEarn } & 0.0335 & 0.0343 & 0.0056 & 0.0401 & 0.0378 & 0.0084 \\
\hline & (1.18) & $(0.99)$ & $(0.10)$ & (1.38) & $(1.07)$ & $(0.14)$ \\
\hline \multirow[t]{2}{*}{ ChtNA } & $0.0570^{*}$ & $0.0646^{*}$ & 0.0223 & $0.0556^{*}$ & $0.0622^{*}$ & 0.0240 \\
\hline & $(2.30)$ & $(2.28)$ & $(0.68)$ & $(2.28)$ & $(2.24)$ & $(0.76)$ \\
\hline \multirow[t]{2}{*}{ ChtRD } & -0.9508 & -0.9014 & 3.1321 & -1.0601 & -1.0618 & 3.4312 \\
\hline & $(-1.23)$ & $(-1.00)$ & $(1.50)$ & $(-1.31)$ & $(-1.12)$ & $(1.82)$ \\
\hline \multirow[t]{2}{*}{ ChtInv } & $0.2566^{*}$ & $0.2617^{*}$ & 0.1646 & $0.2391^{*}$ & $0.2426^{*}$ & 0.1397 \\
\hline & $(2.52)$ & $(2.56)$ & (1.17) & $(2.36)$ & $(2.37)$ & $(0.99)$ \\
\hline \multirow[t]{2}{*}{ ChtDiv } & 0.3875 & 0.3486 & 0.2836 & 0.2908 & 0.2754 & 0.2239 \\
\hline & $(0.71)$ & $(0.66)$ & $(0.48)$ & $(0.56)$ & $(0.55)$ & $(0.40)$ \\
\hline \multirow[t]{2}{*}{ LCash } & $0.4533^{* * *}$ & $0.4434^{* * *}$ & $0.5194^{* * *}$ & $0.4894^{* * *}$ & $0.4808^{* * *}$ & $0.5683^{* * *}$ \\
\hline & $(4.26)$ & $(4.11)$ & $(4.02)$ & $(4.41)$ & $(4.23)$ & $(4.14)$ \\
\hline \multirow[t]{2}{*}{ Lit } & $-0.0554^{* * *}$ & $-0.0516^{* * *}$ & $-0.0395^{* *}$ & $-0.0450^{* * *}$ & $-0.0418^{* * *}$ & $-0.0263^{*}$ \\
\hline & $(-4.37)$ & $(-4.47)$ & $(-3.26)$ & $(-3.67)$ & $(-3.74)$ & $(-2.24)$ \\
\hline \multirow[t]{2}{*}{ NFit } & -0.0156 & -0.0272 & 0.0007 & -0.0093 & -0.0152 & 0.0089 \\
\hline & $(-0.33)$ & $(-0.47)$ & $(0.01)$ & $(-0.20)$ & $(-0.26)$ & $(0.12)$ \\
\hline \multirow[t]{2}{*}{ LCash XChtCash } & & -0.0027 & $-0.0905^{*}$ & & -0.0012 & $-0.0961^{*}$ \\
\hline & & $(-0.29)$ & $(-2.41)$ & & $(-0.12)$ & $(-2.36)$ \\
\hline \multirow[t]{2}{*}{ Lit X LCash } & & $-0.0738^{*}$ & -0.0080 & & $-0.0710^{*}$ & -0.0082 \\
\hline & & $(-2.08)$ & $(-0.18)$ & & $(-1.97)$ & $(-0.17)$ \\
\hline \multirow[t]{2}{*}{ Independence } & & & 0.0923 & & & 0.1017 \\
\hline & & & (1.01) & & & $(1.16)$ \\
\hline \multirow[t]{2}{*}{ Duality } & & & 0.0360 & & & 0.0240 \\
\hline & & & $(0.68)$ & & & $(0.46)$ \\
\hline \multirow[t]{2}{*}{ BoardSize } & & & -0.0068 & & & $-0.0229^{* * *}$ \\
\hline & & & $(-1.23)$ & & & $(-4.21)$ \\
\hline Year Dummy & Yes & Yes & Yes & Yes & Yes & Yes \\
\hline Industry Dummy & Yes & Yes & Yes & Yes & Yes & Yes \\
\hline \multirow[t]{2}{*}{ Intercept } & -0.0476 & -0.0503 & -0.1219 & $-0.1201^{*}$ & $-0.1232^{*}$ & -0.1195 \\
\hline & $(-0.88)$ & $(-0.91)$ & $(-1.34)$ & $(-2.20)$ & $(-2.22)$ & $(-1.34)$ \\
\hline Firm Years & 4407 & 4407 & 2736 & 4407 & 4407 & 2736 \\
\hline $\mathrm{R}^{2}$ & 0.1780 & 0.1798 & 0.1816 & 0.1968 & 0.1985 & 0.2083 \\
\hline $\operatorname{Adj} R^{2}$ & 0.1737 & 0.1752 & 0.1732 & 0.1926 & 0.1939 & 0.2001 \\
\hline $\mathrm{F}$ & 9.4516 & 9.4868 & 6.4602 & 12.6548 & 12.3705 & 9.4007 \\
\hline \multicolumn{7}{|c|}{ Note: $t$ statistics in parentheses } \\
\hline$*, * *$, and $* * *$ indic & iificant at 1 & $5 \%$ and 10 & pectively & & & \\
\hline
\end{tabular}


Table 07: Influence of excess cash and governance on excess returns - FE Analysis

\begin{tabular}{|c|c|c|c|c|c|c|}
\hline \multirow[t]{2}{*}{ Model } & \multirow{2}{*}{\begin{tabular}{|l|}
$(1)$ \\
ERw \\
\end{tabular}} & \multirow{2}{*}{$\begin{array}{l}(2) \\
\text { ERw }\end{array}$} & \multirow{2}{*}{$\begin{array}{l}(3) \\
\text { ERw } \\
\end{array}$} & \multirow{2}{*}{\begin{tabular}{|l|}
$4)$ \\
EReq \\
\end{tabular}} & \multirow{2}{*}{$\begin{array}{l}\text { (5) } \\
\text { EReq } \\
\end{array}$} & \multirow{2}{*}{\begin{tabular}{|l|}
$(6)$ \\
EReq \\
\end{tabular}} \\
\hline & & & & & & \\
\hline \multirow[t]{2}{*}{ excash } & $-2.0109^{* * *}$ & $-0.4793 *$ & $-1.1076^{* * *}$ & $-1.8990^{* * *}$ & $-0.4181 *$ & $-1.0146^{* * *}$ \\
\hline & $(-7.29)$ & $(-2.44)$ & $(-4.84)$ & $(-7.03)$ & $(-2.18)$ & $(-4.53)$ \\
\hline \multirow[t]{2}{*}{ ChtEarn } & $0.1399^{* * *}$ & $0.0532^{*}$ & 0.0168 & $0.1323^{* * *}$ & $0.0495^{*}$ & 0.0154 \\
\hline & $(5.24)$ & $(2.18)$ & $(0.66)$ & $(5.06)$ & $(2.07)$ & $(0.62)$ \\
\hline \multirow[t]{2}{*}{ ChtNA } & 0.0016 & 0.0196 & 0.0236 & 0.0010 & 0.0192 & 0.0228 \\
\hline & $(0.10)$ & $(1.28)$ & $(1.55)$ & $(0.07)$ & $(1.28)$ & $(1.53)$ \\
\hline \multirow[t]{2}{*}{ ChtRD } & $3.6259^{* *}$ & $3.8045^{* *}$ & $3.7254^{* *}$ & $3.6948^{* *}$ & $3.8765^{* *}$ & $3.7914^{* *}$ \\
\hline & $(2.84)$ & (2.94) & $(2.90)$ & $(2.95)$ & (3.07) & (3.01) \\
\hline \multirow[t]{2}{*}{ ChtInv } & 0.0149 & 0.0076 & -0.0520 & 0.0145 & 0.0080 & -0.0486 \\
\hline & $(0.30)$ & $(0.15)$ & $(-1.00)$ & $(0.30)$ & $(0.16)$ & $(-0.96)$ \\
\hline \multirow[t]{2}{*}{ ChtDiv } & $1.2298^{* * *}$ & $1.2969^{* * *}$ & $1.2468^{* * *}$ & $1.2033^{* * *}$ & $1.2719^{* * *}$ & $1.2273^{* * *}$ \\
\hline & $(3.40)$ & $(3.54)$ & $(3.42)$ & $(3.40)$ & (3.55) & (3.44) \\
\hline \multirow[t]{2}{*}{ LCash } & $1.3809^{* * *}$ & $0.9599^{* * *}$ & $1.0316^{* * *}$ & $1.2902^{* * *}$ & $0.8845^{* * *}$ & $0.9590^{* * *}$ \\
\hline & $(7.02)$ & $(4.93)$ & $(5.43)$ & $(6.70)$ & $(4.65)$ & $(5.16)$ \\
\hline \multirow[t]{2}{*}{ Lit } & $-0.0732^{* * *}$ & $-0.0646^{* *}$ & $-0.0632^{* *}$ & $-0.0568^{* *}$ & $-0.0483^{*}$ & $-0.0471^{*}$ \\
\hline & $(-3.45)$ & $(-3.02)$ & $(-2.97)$ & $(-2.74)$ & $(-2.31)$ & $(-2.27)$ \\
\hline \multirow[t]{2}{*}{ NFit } & $0.2418^{* * *}$ & $0.2098^{* * *}$ & $0.2365^{* * *}$ & $0.2425^{* * *}$ & $0.2114^{* * *}$ & $0.2364^{* * *}$ \\
\hline & $(9.38)$ & $(8.15)$ & $(9.03)$ & $(9.60)$ & $(8.40)$ & $(9.22)$ \\
\hline \multirow[t]{2}{*}{$\begin{array}{l}\text { excash X } \\
\text { Independence }\end{array}$} & $1.6690^{* * *}$ & & & $1.6156^{* * *}$ & & \\
\hline & $(7.86)$ & & & (7.77) & & \\
\hline \multirow[t]{2}{*}{ Independence } & 0.0889 & & & 0.0742 & & \\
\hline & $(0.65)$ & & & $(0.56)$ & & \\
\hline \multirow[t]{2}{*}{ excash X Duality } & & 0.0861 & & & 0.0399 & \\
\hline & & $(0.37)$ & & & $(0.17)$ & \\
\hline \multirow[t]{2}{*}{ Duality } & & 0.1666 & & & 0.1648 & \\
\hline & & (1.86) & & & $(1.88)$ & \\
\hline \multirow[t]{2}{*}{ BoardSize } & & & $-0.0287^{*}$ & & & $-0.0345^{* *}$ \\
\hline & & & $(-2.36)$ & & & $(-2.90)$ \\
\hline \multirow[t]{2}{*}{ excash X BoardSize } & & & $0.1187^{* * *}$ & & & $0.1110^{* * *}$ \\
\hline & & & (4.99) & & & $(4.77)$ \\
\hline \multirow[t]{2}{*}{ Intercept } & $-0.3525^{* * *}$ & -0.0209 & -0.0290 & $-0.3912^{* * *}$ & -0.0404 & -0.0485 \\
\hline & $(-3.32)$ & $(-0.26)$ & $(-0.36)$ & $(-3.76)$ & $(-0.50)$ & $(-0.61)$ \\
\hline Firm years & 2714 & 2714 & 2714 & 2714 & 2714 & 2714 \\
\hline $\mathrm{R}^{2}$ & 0.1453 & 0.1259 & 0.1341 & 0.1444 & 0.1267 & 0.1341 \\
\hline Adj $R^{2}$ & -0.0342 & -0.0582 & -0.0478 & -0.0354 & -0.0572 & -0.0478 \\
\hline $\mathrm{F}$ & 34.6550 & 26.8953 & 31.5763 & 34.3962 & 27.1013 & 31.5739 \\
\hline
\end{tabular}

\section{Conclusion}

The present study examines the level of cash holdings of Australian firms for the period 2004 to 2010 and analyses the influence of level of cash holdings and excess cash as well as the impact of governance on the value of firms. Australian firms on average hold 32.2 per cent of assets in cash and this ratio increased to a high level of 48.5 per cent in 2010. Concerns relating to global financial crisis and the desire of companies to meet unanticipated expenses may have led to this increase in cash holdings. Similarly firms may also want to hold these higher cash balances for speculative purposes as new opportunities arise, firms may want minimize the cost of raising external financing. Fixed effects analysis shows that excess cash has a significant negative influence on the value of firms while profitability, growth opportunities and dividend payout as well as level of cash holdings have a positive significant influence on the value. Leverage on the other hand has a significant negative influence on the value of firms. The present study also provides evidence that good governance can help firms improve value when holding excess cash as investors interests are protected by independent and large boards. 


\section{References}

Chang, K. \& Noorbakhsh, A. (2006). Corporate cash holdings, foreign direct investment, and corporate governance. Global Finance Journal, 16(3), 302-316.

Chen, Y. R. \& Chuang, W. T. (2009). Alignment or entrenchment? Corporate governance and cash holdings in growing firms. Journal of Business Research, 62(11), 1200-1206.

Dittmar, A. \& Mahrt-Smith, J. (2007). Corporate governance and the value of cash holdings. Journal of Financial Economics, 83(3), 599-634.

Drobetz, W. \& Grüninger, M. C. (2007). Corporate cash holdings: Evidence from Switzerland. Financial Markets and Portfolio Management, 21(3), 293-324.

Fama, E. F. \& French, K. R. (1993). Common risk factors in the returns on stocks and bonds. Journal of Financial Economics, 33(1), 3-56. doi: 10.1016/0304-405x(93)90023-5

Faulkender, M. \& Wang, R. (2006). Corporate Financial Policy and the Value of Cash. The Journal of Finance, 61(4), 1957-1990.

Frésard, L. L. \& Salva, C. (2010). The value of excess cash and corporate governance: Evidence from US cross-listings. Journal of Financial Economics, 98(2), 359-384.

Harford, J., Mansi, S. A. \& Maxwell, W. F. (2008). Corporate governance and firm cash holdings in the US. Journal of Financial Economics, 87(3), 535-555.

Jensen, M. C. \& Meckling, W. H. (1976). Theory of the firm: Managerial behavior, agency costs and ownership structure. Journal of Financial Economics, 3(4), 305-360. doi: 10.1016/0304405x(76)90026-x

Kim, C. S., Mauer, D. C. \& Sherman, A. E. (1998). The Determinants of Corporate Liquidity: Theory and Evidence. [10.2307/2331099]. Journal of Financial and Quantitative Analysis, 33(03), 335-359.

Kuan, T. H., Li, C. S. \& Chu, S. H. (2011). Cash holdings and corporate governance in family-controlled firms. Journal of Business Research, 64(7), 757-764.

Kuan, T. H., Li, C. S. \& Liu, C. C. (2012). Corporate governance and cash holdings: A quantile regression approach. International Review of Economics and Finance, 24, 303-314.

Kusnadi, Y. (2011). Do corporate governance mechanisms matter for cash holdings and firm value? Pacific Basin Finance Journal, 19(5), 554-570.

Lee, K. W. \& Lee, C. F. (2009). Cash holdings, corporate governance structure and firm valuation. Review of Pacific Basin Financial Markets and Policies, 12(3), 475-508.

Lins, K. V., Servaes, H. \& Tufano, P. (2010). What drives corporate liquidity? An international survey of cash holdings and lines of credit. Journal of Financial Economics, 98(1), 160-176. doi: 10.1016/j.jfineco.2010.04.006

Liu, Y. \& Mauer, D. C. (2011). Corporate cash holdings and CEO compensation incentives. Journal of Financial Economics, 102(1), 183-198.

Opler, T., Pinkowitz, L., Stulz, R. \& Williamson, R. (1999). The determinants and implications of corporate cash holdings. Journal of Financial Economics, 52(1), 3-46.

Ozkan, A. \& Ozkan, N. (2004). Corporate cash holdings: An empirical investigation of UK companies. Journal of Banking and Finance, 28(9), 2103-2134.

Pinkowitz, L., Stulz, R. \& Williamson, R. (2006). Does the contribution of corporate cash holdings and dividends to firm value depend on governance? A cross-country analysis. Journal of Finance, 61(6), 2725-2751.

Powell, G. E. \& Baker, H. K. (2010). Management Views on Corporate Cash Holdings. Journal of Applied Finance, 20(2), 155-168. 